\title{
Front Matter: Volume 6638
}

, "Front Matter: Volume 6638," Proc. SPIE 6638, Photonic Metamaterials, 663801 (3 October 2007); doi: 10.1117/12.773741

SPIE Event: NanoScience + Engineering, 2007, San Diego, California, United SPIE. States 


\title{
PROCEEDINGS OF SPIE
}

\section{Photonic Metamaterials}

\author{
Mikhail A. Noginov \\ Nikolay I. Zheludev \\ Allan D. Boardman \\ Nader Engheta \\ Editors
}

26-28 August 2007

San Diego, California, USA

Sponsored and Published by

SPIE

Volume 6638 
The papers included in this volume were part of the technical conference cited on the cover and title page. Papers were selected and subject to review by the editors and conference program committee. Some conference presentations may not be available for publication. The papers published in these proceedings reflect the work and thoughts of the authors and are published herein as submitted. The publisher is not responsible for the validity of the information or for any outcomes resulting from reliance thereon.

Please use the following format to cite material from this book:

Author(s), "Title of Paper," in Photonic Metamaterials, edited by Mikhail A. Noginov,

Nikolay I. Zheludev, Allan D. Boardman, Nader Engheta, Proceedings of SPIE Vol. 6638 (SPIE, Bellingham, WA, 2007) Article CID Number.

ISSN 0277-786X

ISBN 9780819467867

Published by

SPIE

P.O. Box 10, Bellingham, Washington 98227-0010 USA

Telephone +1 3606763290 (Pacific Time) · Fax +1 3606471445

SPIE.org

Copyright (C) 2007, Society of Photo-Optical Instrumentation Engineers

Copying of material in this book for internal or personal use, or for the internal or personal use of specific clients, beyond the fair use provisions granted by the U.S. Copyright Law is authorized by SPIE subject to payment of copying fees. The Transactional Reporting Service base fee for this volume is $\$ 18.00$ per article (or portion thereof), which should be paid directly to the Copyright Clearance Center (CCC), 222 Rosewood Drive, Danvers, MA 01923. Payment may also be made electronically through CCC Online at copyright.com. Other copying for republication, resale, advertising or promotion, or any form of systematic or multiple reproduction of any material in this book is prohibited except with permission in writing from the publisher. The CCC fee code is 0277-786X/07/ \$18.00.

Printed in the United States of America.

Publication of record for individual papers is online in the SPIE Digital Library.

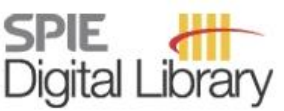

SPIEDigitalLibrary.org

Paper Numbering: Proceedings of SPIE follow an e-First publication model, with papers published first online and then in print and on CD-ROM. Papers are published as they are submitted and meet publication criteria. A unique, consistent, permanent citation identifier (CID) number is assigned to each article at the time of the first publication. Utilization of CIDs allows articles to be fully citable as soon they are published online, and connects the same identifier to all online, print, and electronic versions of the publication. SPIE uses a six-digit CID article numbering system in which:

- The first four digits correspond to the SPIE volume number.

- The last two digits indicate publication order within the volume using a Base 36 numbering system employing both numerals and letters. These two-number sets start with 00, 01, 02, 03, 04, 05, 06, 07, 08, 09, OA, OB ... 0Z, followed by 10-1Z, 20-2Z, etc.

The CID number appears on each page of the manuscript. The complete citation is used on the first page, and an abbreviated version on subsequent pages. Numbers in the index correspond to the last two digits of the six-digit CID number. 


\section{Contents}

vii Conference Committee

\section{SESSION 1 SURFACE PLASMONS}

663803 Two-dimensional plasmonic metamaterials (Invited Paper) [6638-02]

I. I. Smolyaninov, Y.-J. Hung, C. C. Davis, Univ. of Maryland, College Park (USA)

663804 Fabrication of plasmonic waveguides for device applications (Invited Paper) [6638-32] A. Boltasseva, Technical Univ. of Denmark (Denmark); K. Leosson, T. Rosenzveig, Univ. of Iceland (Iceland); R. B. Nielsen, R. H. Pedersen, K. B. Jørgensen, Technical Univ. of Denmark (Denmark); I. Fernandez-Cuesta, Technical Univ. of Denmark (Denmark) and Univ.

Autònoma de Barcelona (Spain); J. Jung, T. Søndergaard, S. I. Bozhevolnyi, Aalborg Univ. (Denmark); A. Kristensen, Technical Univ. of Denmark (Denmark)

663805 Optical metamaterials based on thin metal films: from negative index of refraction, to enhanced transmission, to surface wave guidance (Invited Paper) [6638-04]

V. Lomakin, Y. Fainman, Univ. of California, San Diego (USA); Y. Urzhumov, G. Shvets, Univ. of Texas, Austin (USA)

663806 En route to low loss nanoplasmonics: elongating surface plasmon propagating length without gain [6638-05]

G. Zhu, M. Mayy, M. Bahoura, B. A. Ritzo, V. I. Gavrilenko, M. A. Noginov, Norfolk State Univ. (USA)

\section{SESSION 2 OPTICAL MAGNETISM AND NIMS}

663808 Photon tunneling at material boundary by positive permeability metamaterials [6638-07] A. Ishikawa, Nanophotonics Lab., RIKEN (Japan), Osaka Univ. (Japan), and Univ. of California, Berkeley (USA); T. Tanaka, Nanophotonics Lab., RIKEN (Japan) and JST PRESTO (Japan); S. Kawata, Nanophotonics Lab., RIKEN (Japan), Osaka Univ. (Japan), and JST CREST (Japan)

6638 OA Slow light in negative-index waveguide heterostructures (Invited Paper) [6638-10] K. L. Tsakmakidis, D. P. Aryal, O. Hess, Univ. of Surrey (United Kingdom)

\section{SESSION 3 NIMS}

$6638 \mathrm{OF}$ The effects of dispersion, diffraction, and nonlinearity management in negative index materials [6638-15]

P. P. Banerjee, G. Nehmetallah, Univ. of Dayton (USA)

6638 OG Mean field theory of metallo-dielectric photonic crystals with magnetic components: the long-wavelength limit [6638-16]

E. Reyes-Ayona, P. Halevi, Instituto Nacional de Astrofísica, Óptica y Electrónica (Mexico) 
$6638 \mathrm{OH}$ Fabrication and applications of negative refractive index matermaterials with chiral properties [6638-17]

E. Bahar, N. J. Ianno, Univ. of Nebraska-Lincoln (USA)

\section{SESSION 4 COMPOSITES, INTERFACES, AND MATERIALS}

$6638 \mathrm{Ol} \quad$ Organic electro-optic/silicon photonic materials and devices (Invited Paper) [6638-18]

L. R. Dalton, P. A. Sullivan, B. C. Olbricht, Y. Takimoto, J. J. Rehr, B. E. Eichinger, A. A. Mistry,

D. Bale, H. Rommel, B. Robinson, Univ. of Washington (USA)

6638 OK Effect of interchain interaction on linear optical properties of poly(thienylenevinylene) [6638-21]

A. V. Gavrilenko, T. D. Matos, C. E. Bonner, V. I. Gavrilenko, S.-S. Sun, C. Zhang, Norfolk State Univ. (USA)

$6638 \mathrm{OL}$ Semiclassical theory of hyperlensing and cloaking [6638-41]

Z. Jacob, L. V. Alekseyev, Princeton Univ. (USA); E. Narimanov, Purdue Univ. (USA)

\section{SESSION 5 FUNDAMENTALS AND CONCEPTS}

$66380 \mathrm{M}$ Light pressure on chiral sculptured thin films (Invited Paper) [6638-25]

B. M. Ross, A. Lakhtakia, Pennsylvania State Univ. (USA)

663800 Swamping of circular Bragg phenomenon revealed by durations and average speeds of videopulses transmitted through chiral sculptured thin films [6638-27]

J. B. Geddes III, Univ. of Illinois at Urbana-Champaign (USA); A. Lakhtakia, Pennsylvania State Univ. (USA)

\section{SESSION 6 LUMINESCENCE, GAIN, AND LASING}

6638 OP On the possibility of gain control and special solitons in metamaterials (Invited Paper) [6638-28]

A. D. Boardman, N. King, Univ. of Salford (United Kingdom); Y. Rapoport, National Taras Shevchenko Univ. (Ukraine)

$66380 Q$ Diffraction and dispersion management in active nanostructured metamaterials (Invited Paper) [6638-29]

V. A. Podolskiy, A. A. Govyadinov, Oregon State Univ. (USA)

6638 OR Limits of luminescence efficiency enhancement by surface plasmon polaritons (Invited Paper) [6638-30]

J. B. Khurgin, Johns Hopkins Univ. (USA); G. Sun, Univ. of Massachussetts, Boston (USA)

6638 OS Dye-doped porous silica as an all solid state device for random lasing [6638-31] M. Berard, Thales Research and Technology (France) and Physique de la Matiere Condensée Ecole Polytechnique, CNRS (France); V. Rachet, Saint Gobain Recherche (France); K. Lahlil, T. Gacoin, Physique de la Matiere Condensée Ecole Polytechnique, CNRS (France); J. P. Galaup, Lab. Aimé Cotton (France); J. P. Boilot, Physique de la Matiere Condensée Ecole Polytechnique, CNRS (France) 


\section{SESSION 7 DEVICES AND SYSTEMS}

6638 OU Characterization and excitation of a nano-scaled plasmonic coupler with co-directional phase and contra-directional power flow (Invited Paper) [6638-33]

Y. Wang, K. Zeaiter, A. S. Helmy, G. V. Eleftheriades, Univ. of Toronto (Canada)

6638 OW Optical hyperlens: far-field imaging beyond the diffraction limit (Invited Paper) [6638-35] Z. Jacob, L. Alekseyev, Princeton Univ. (USA); E. Narimanov, Purdue Univ. (USA)

\section{POSTER SESSION}

$6638 \mathrm{OZ}$ Optical properties of metamaterials based on porous channel photonic structures and applications for optical devices [6638-23]

E. Ya. Glushko, Institute of Semiconductor Physics (Ukraine)

663810 Electrically controlled Bragg resonances of an ambichiral electro-optic structure: oblique incidence [6638-38]

M. Dixit, A. Lakhtakia, Pennsylvania State Univ. (USA)

663811 Equilibrium geometries and electronic structure calculations of divalent lead $\mathrm{Pb}$ (II) complexes with paramagnetic organic ligands [6638-39]

H. Li, R. Bah, R. Rakhimov, V. I. Gavrilenko, Norfolk State Univ. (USA)

Author Index 
Downloaded From: https://www.spiedigitallibrary.org/conference-proceedings-of-spie on 26 Apr 2023

Terms of Use: https://www.spiedigitallibrary.org/terms-of-use 


\title{
Conference Committee
}

\author{
Symposium Chairs
}

David L. Andrews, University of East Anglia Norwich (United Kingdom) James G. Grote, Air Force Research Laboratory (USA)

Kevin J. Liddane, Oerlikon Optics USA, Inc. (USA)

\section{Conference Chairs}

Mikhail A. Noginov, Norfolk State University (USA)

Nikolay I. Zheludev, University of Southampton (United Kingdom)

Allan D. Boardman, University of Salford (United Kingdom)

Nader Engheta, University of Pennsylvania (USA)

Program Committee

David L. Andrews, University of East Anglia Norwich (United Kingdom)

Hui Cao, Northwestern University (USA)

Larry R. Dalton, University of Washington (USA)

Graeme Dewar, University of North Dakota (USA)

Ildar R. Gabitov, University of Arizona (USA)

Alexander L. Gaeta, Cornell University (USA)

F. Javier Garcia de Abajo, Consejo Superior de Investigaciones Científicas (Spain)

Jacob B. Khurgin, Johns Hopkins University (USA)

Joachim R. Krenn, Karl-Franzens-Universität Graz (Austria)

Akhlesh Lakhtakia, Pennsylvania State University (USA)

Martin W. McCall, Imperial College London (United Kingdom)

Martin Moskovits, University of California, Santa Barbara (USA)

Evgenii E. Narimanov, Purdue University (USA)

Andrey K. Sarychev, Ethertronics, Inc. (USA)

Vladimir M. Shalaev, Purdue University (USA)

Gennady Shvets, University of Texas, Austin (USA)

Mark I. Stockman, Georgia State University (USA)

Din-Ping Tsai, National Taiwan University (Taiwan)

\section{Session Chairs}

1 Keynote Session I

Mikhail A. Noginov, Norfolk State University (USA) 
2 Surface Plasmons

Allan D. Boardman, University of Salford (United Kingdom)

3 Optical Magnetism and NIMs

Nikolay I. Zheludev, University of Southampton (United Kingdom)

$4 \quad$ Metamaterials in IR Range

Akhlesh Lakhtakia, Pennsylvania State University (USA)

5 NIMs

Philip A. Sullivan, University of Washington (USA)

6 Composites, Interfaces, and Materials

Akhlesh Lakhtakia, Pennsylvania State University (USA)

$7 \quad$ Fundamentals and Concepts

F. J. Garcia de Abajo, Consejo Superior de Investigaciones Científicas (Spain)

8 Luminescence, Gain, and Lasing

Vladimir M. Shalaev, Purdue University (USA)

9 Devices and Systems

Nader Engheta, University of Pennsylvania (USA)

10 Keynote Session II

Allan D. Boardman, University of Salford (United Kingdom) 